\title{
Tinjauan Yuridis Peninjauan Kembali yang Diajukan oleh Jaksa Penuntut Umum Terhadap Putusan Lepas dari Segala Tuntutan Hukum
}

\author{
M. Jordan Pradana, Syofyan Nur, Erwin \\ Fakultas Hukum, Universitas Jambi \\ Author's email correspondence: jordandanismant@gmail.com
}

\section{ABSTRAK}

Penelitian ini bertujuan untuk mengetahui secara yuridis terhadap kedudukan Jaksa Penuntut Umum dalam mengajukan upaya hukum Peninjauan Kembali kepada Mahkamah Agung. Peninjauan Kembali berdasarkan Pasal 263 ayat (1) hanya dapat dilakukam oleh terpidana atau ahli waris terpidana, namun pada kenyataannya Jaksa Penuntut Umum pernah mengajukan permintaan Peninjauan Kembali dan diterima oleh Mahkamah Agung. Metode yang digunakan dalam penelitian ini adalah penelitian normatif yaitu pendekatan yang menggunakan konsep logis positivis yang menyatakan bahwa hukum adalah identik dengan normanorma tertulis yang dibuat dan diundang oleh lembaga-lembaga atau pejabat yang berwenang. Hasil penelitian diketahui bahwa terdapat kekosongan norma hukum mengenai kedudukan Jaksa Penuntut Umum dalam mengajukan permintaan Peninjauan Kembali dan menyarankan dibentuknya aturan khusus mengenai kedudukan Jaksa Penuntut Umum dalam mengajukan peninjauan kembali. Kesimpulan yaitu Sesuai dengan Pasal 263 ayat (1) KUHAP Jaksa Penuntut Umum tidak berhak mengajukan peninjauan kembali, karena yang berhak mengajukan peninjauan kembali hanya terpidana dan ahli warisnya dan peninjauan kembali tidak bisa dilakukan terhadap putusan bebas atau putusan lepas dari segala tuntutan hukum dan diperlukan aturan khusus mengenai peninjauan kembali yang diajukan oleh Jaksa Penuntut Umum, sehingga terwujudnya keadilan, kepastian hukum, dan kemanfaatan hukum.
\end{abstract}

\section{ARTICLE HISTORY}

Submission: 2020-06-11

Accepted: 2020-10-07

Publish: 2020-10-10

KEYWORDS: Judicial Review, Reconsideration, Public Prosecutors.

\section{ABSTRACT}

This study aims to find out juridically about the position of the public prosecutor in filing legal remedies for judicial review to the Supreme Court. A review based on Article 263 paragraph (1) can only be carried out by the convict or the convict's heirs, but in reality the Public Prosecutor has submitted a request for reconsideration and was accepted by the Supreme Court. The method used in this research is normative research, which is an approach that uses a positivist logical concept which states that law is identical to written norms made and invited by authorized institutions or officials. The results of the study show that there is a vacuum in legal norms regarding the position of the Public Prosecutor in submitting a request for reconsideration and suggesting the formation of special rules regarding the position of the Public Prosecutor in filing a review. The conclusion is that in accordance with Article 263 paragraph (1) of the Criminal Procedure Code, the Public Prosecutor has no right to file a review, because only the convict and his heirs are entitled to apply for a review and the review cannot be carried out against an acquittal or a decision to be released from all lawsuits and regulations are required. specifically regarding the review submitted by the Public Prosecutor, so that justice, legal certainty and legal benefits can be realized. 


\section{A. PENDAHULUAN}

Menurut Gustav Radbruch, tujuan hukum adalah untuk mencapai keadilan, kemanfaatan dan memberikan kepastian hukum. Salah satu tujuan dari hukum adalah memberikan manfaat bagi masyarakat, dan oleh karena itulah hukum harus dinamis dan sesuai dengan perkembangan pada masa ini agar tercapailah tujuan hukum yang dimaksud yaitu bermanfaat bagi masyarakat dalam rangka penciptaan ketertiban dalam tatanan kehidupan bermasyarakat ${ }^{1}$. Secara singkat didefinisikan bahwa hukum acara pidana adalah hukum yang mengatur tentang bagaimana cara mempertahankan atau menyelenggarakan hukum pidana materil, sehingga memperoleh keputusan hakim dan cara bagaimana isi keputusan itu harus dilaksanakan. Demikian pula J.C.T. Simorangkir mengemukakan pengertian hukum acara pidana yaitu "hukum acara yang melaksanakan dan mempertahankan hukum pidana materil2.

Masalah peninjauan kembali (PK) perkara pidana yang telah memperoleh kekuatan hukum tetap, belakangan menimbulkan perdebatan di berbagai kalangan. Pemikiran Moh. Mahfud MD dan M. Khoidin yang dimuat di dalam Republika edisi 2 desember 1996, memunculkan perbedaan yang mencolok tentang penafsiran isi pasal 263 KUHAP. Sementara Achmad Ali, dekan Fakultas Humas Universitas Hasanuddin, meninjau isi Pasal 263 KUHAP dari segi pengetahuan hukum dan ilmu hukum. Dalam Kitab Undang-Undang Hukum Acara Pidana (KUHAP) Pasal 263 ayat (1) disebutkan bahwa untuk memenuhi rasa keadilan bagi para pencari keadilan, dibuka kemungkinan upaya hukum bagi terpidana, yaitu perkara yang sudah diputus oleh pengadilan dan putusan tersebut sudah berkekuatan hukum tetap yaitu melalui Peninjauan Kembali (PK) kepada Mahkamah Agung. Dalam praktik hukum perumusan Pasal 263 Kitab Undang-undang Hukum Acara Pidana (KUHAP) telah menimbulkan kontroversial di kalangan praktisi, akademisi dan pejabat penegak hukum. Sebagian diantara mereka menyatakan bahwa yang berhak mengajukan Peninjauan Kembali (PK) hanyalah terpidana atau ahli warisnya ${ }^{3}$.

Upaya hukum Peninjauan Kembali putusan pidana yang telah mempunyai kekuatan hukum tetap (inkracht van gewijsde) merupakan upaya hukum luar biasa yang diatur di dalam Undang-Undang No. 8 Tahun 1981 Tentang Hukum Acara Pidana, (KUHAP). Berdasarkan ketentuan Pasal 263 Ayat (1) KUHAP, diatur bahwa "Terhadap putusan pengadilan yang telah memperoleh kekuatan hukum tetap, kecuali putusan bebas atau lepas dari segala tuntutan hukum, terpidana atau ahli warisnya dapat mengajukan permintaan peninjauan kembali kepada Mahkamah Agung". Pasal ini dapat ditarik dua makna yaitu pertama, tidak dapat dilakukan upaya peninjauan kembali terhadap putusan bebas atau putusan lepas dari segala tuntutan hukum. Kedua, peninjauan kembali merupakan upaya hukum yang ditujukan untuk melindungi

1 Asriandi, "Kepastian Hukum Peninjauan Kembali Pasca Putusan Mahkamah Konstitusi Nomor 34/PUU-XI/2013 dan Surat Edaran Mahkamah Agung Nomor \& Tahun 2014 Di Pengadilan Negeri Makassar", Skripsi Sarjana Hukum UIN Alauddin, Makassar, 2017, hlm. 12.

2 Andi Sofyan dan Abd. Asis, Hukum Acara Pidana Suatu Pengantar, Edisi Pertama, Kencana Pramedia Group, Jakarta, 2014, hlm. 4.

3 Yayang Susila Sakti, "Peninjauan Kembali oleh Jaksa Penuntut Umum antara Kepastian dan Keadilan,"Arena Hukum Volume 7, No. 1. Edisi April 2014, hlm. 69. 
kepentingan terhukum sehingga hanya terpidana atau ahli warisnya yang berhak mengajukan ${ }^{4}$.

Mahkamah Agung sebelumnya pernah menerima upaya Peninjauan Kembali yang diajukan oleh Jaksa Penuntut Umum terhadap terdakwa Mochtar Pakpahan pada tahun 1996. Kemudian pada tahun 2001, Mahkamah Agung menerima Peninjauan Kembali dengan terdakwa Ram Gulumal. Pada Tahun 2006, Mahkamah Agung juga menerima Peninjauan Kembali dengan terdakwa Soetyawati dan tahun 2007, pengajuan Peninjauan Kembali oleh Jaksa Penuntut Umum atas terdakwa Pollycarpus juga diterima oleh Mahkamah Agung dengan salah satu dasar pertimbangan putusannya adalah consistency of court decision. Demikian juga pakar hukum Universitas Brawijaya DR.Adami Chazawi dalam bukunya Lembaga Peninjauan Kembali (PK) Perkara Pidana: Penegakan Hukum dalam Penyimpangan Praktik dan Peradilan Sesat menyebutkan bahwa putusan Mahkamah Agung yang membenarkan alasan pengajuan permintaan Peninjauan Kembali Penuntut Umum, merupakan putusan yang dengan jelas memperlihatkan suatu kekhilafan Hakim atau suatu kekeliruan yang nyata sebagaimana dimaksud Pasal 263 ayat (2) huruf c KUHAP5.

Polemik ini tidak menyurutkan langkah Mahkamah Agung untuk menerima pengajuan Peninjauan Kembali oleh Jaksa Penuntut Umum sebagaimana dalam putusan perkara Djoko S. Tjandra No.12PK/Pid.Sus/2009. Fenomena ini menarik untuk dikaji dalam sebuah penelitian terkait kenyataan dalam praktek menyangkut konsistensi terhadap asas-asas hukum acara pidana maupun teori dan norma hukum pidana berkenaan dengan eksistensi dan tujuan pengaturan upaya hukum peninjauan kembali putusan pidana yang berkuatan hukum tetap6. Peninjauan Kembali dibentuk untuk ditujukan bagi kepentingan terpidana, bukan kepentingan negara atau korban. Ketentuan ini berpijak pada dasar filosofi, bahwa negara telah salah mempidana penduduk yang tidak berdosa yang dapat diperbaiki lagi dengan upaya hukum biasa. Tidak dibenarkan negara berdiam diri menghadapi penduduk yang tidak berdosa terlanjur dipidana. Putusan menjatuhkan pidana pada orang yang tidak bersalah yang telah tetap, membawa akibat telah dirampasnya keadilan dan hak-hak terpidana secara tidak sah. Negara telah berdosa mempidana penduduk negara yang tidak bersalah. Bentuk penebusan dosa tersebut yakni negara memberikan hak kepada terdakwa untuk melawan putusan yang salah tersebut. PK berfungsi untuk mengembalikan hak dan keadilan terpidana yang terlanjur dirampas negara secara tidak sah? ${ }^{7}$.

Meskipun sekarang ini KUHAP telah berusia lebih dari dua puluh satu tahun, namun berlakunya Pasal 263 KUHAP yang mengatur tentang upaya hukum luar biasa yang dinamakan peninjauan kembali (PK) dalam pelaksanaannya masih menimbulkan perbedaan pendapat yang kontroversial ${ }^{8}$. Mardjono Reksodiputro dalam Efi Laila, mengemukakan bahwa apabila keterpaduan dalam sistem peradilan pidana tidak dilakukan maka diperkirakan akan terdapat tiga kerugian sebagai berikut:

4 Budi Suhariyanto, "Peninjauan Kembali Putusan Pidana Oleh Jaksa Penuntut Umum", Hasil Penelitian, Mahkamah Agung RI, 2012, hlm.1.

5 Ibid., hlm. 8.

6 Ibid., hlm. 9.

7 Yayang Susila Sakti, Loc.Cit.

8 Hma Kuffal, Penerapan KUHAP dalam Praktik Hukum. Edisi Revisi, Cetakan Kesembilan, UPT Penerbitan Universitas Muhammadiyah Malang, Malang, 2007, hlm.232. 
1. Kesukaran dalam menilai sendiri keberhasilan atau kegagalan masing-masing instansi, sehubungan dengan tugas mereka bersama;

2. Kesulitan dalam memecahkan sendiri masalah-masalah pokok masing-masing instansi (sebagai subsistem dari sistem peradilan pidana; dan

3. Karena tanggung jawab masing-masing instansi sering kurang jelas terbagi, maka setiap instansi tidak terlalu memperhatikan efektifitas menyeluruh sistem peradilan pidana. ${ }^{9}$

Demikian yang melatarbelakangi permasalahan dari upaya Peninjauan Kembali yang diajukan oleh Jaksa Penuntut Umum. Maka penulis menyimpulkan adanya kekosongan hukum mengenai kedudukan Jaksa Penuntut Umum dalam mengajukan Peninjauan Kembali. Berdasarkan permasalahan ini maka penulis akan membahas maslaah mengenai bagaimana kedudukan Jaksa Penuntut Umum dalam mengajukan upaya hukum Peninjauan Kembali terhadap putusan lepas dari segala tuntutan hukum dan apakah diperlukan pengaturan khusus mengenai Peninjauan Kembali yang diajukan oleh Jaksa Penuntut Umum terhadap putusan lepas dari segala tuntutan hukum.

\section{B. METODE PENELITIAN}

Jenis penelitian yang digunakan adalah merupakan penelitian hukum Yuridis Normatif yaitu metode penelitian hukum yang dilakukan dengan pendekatan teori dan metode analisis yang termasuk dalam disiplin ilmu hukum yang dogmatis ${ }^{10}$. Yuridis Normatif yaitu metode yang meneliti berdasarkan kepustakan yang menggunakan bahan-bahan literatur seperti buku-buku, undang-undang yang berlaku, dokumendokumen serta media lainnya yang dapat dijadikan bahan data atau teori yang menjadi pokok permasalahan dalam penelitian. Yuridis Normatif tinjauannya dilakukan dengan berpegang pada metode dogmatik ${ }^{11}$. Sifat penelitian bersifat deskriptif yaitu menjelaskan suatu masalah yang merupakan tentang bagaimana kedudukan Jaksa Penuntut Umum dalam mengajukan upaya hukum Peninjauan Kembali.

\section{PEMBAHASAN}

\section{Kedudukan Jaksa Penuntut Umum dalam mengajukan PK.}

Jaksa Penuntut Umum adalah pejabat fungsional negara yang diberi wewenang oleh undang-undang untuk bertindak sebagai penuntut umum dan pelaksanaan putusan pengadilan yang telah memperoleh kekuatan hukum dan melakukan penuntutan serta melaksanakan penetapan hakim ${ }^{12}$. Sebelum berlakunya KUHAP, belum ada undang-undang yang mengatur pelaksanaan peninjauan kembali putusan pengadilan yang telah mempunyai kekuatan hukum tetap. Pasal 21 Undang-Undang No. 4 Tahun 2004 yang sekarang diganti dengan Pasal 24 Undang-Undang No. 48 Tahun 2009 tentang Kekuasaan Kehakiman hanya menyebutkan kemungkinan

9 Sahuri Lasmadi. Tumpang Tindih Kewenangan Penyidikan Pada Tindak Pidana Korupsi Dalam Perspektif Sistem Peradilan Pidana. Artikel Dosen Fakultas Hukum Universitas Jambi. hlm. 34.

10 Ronny Hanitijo Soemitro, Metodologi Penelitian Hukum dan Jurimetri, Ghalia Indonesia, Jakarta, 1990, hlm. 34.

11 Bahder Johan Nasution, Metode Penelitian Ilmu Hukum, Mandar Maju, Bandung, 2016. hlm. 91.

12 www.negarahukum.com, Diakses Pada Tanggal 07-11-2019 Pada Pukul 09.30 WIB. 
peninjauan kembali itu, tetapi pelaksanaannya sesuai dengan ketentuan undangundang. kemudian Mahkamah Agung mengeluarkan Peraturan Mahkamah Agung Nomor 1 Tahun1980 yang mengatur kemungkinan mengajukan peninjauan kembali, baik perkara perdata maupun pidana.

Upaya pengajuan peninjauan kembali telah diatur dalam pasal-pasal antara lain: Pasal 263, 264, 265, 266, 267, 268, dan 269 KUHAP. Sesuai dengan Pasal 263 ayat (1) KUHAP yang berbunyi: Terhadap putusan pengadilan yang telah memperoleh kekuatan hukum tetap, kecuali putusan bebas atau lepas dari segala tuntutan huku, terpidana atau ahli warisnya dapat mengajukan permintaan peninjauan kembali kepada Mahkamah Agung. Pasal 263 ayat (1) sudah jelas dan dapat disimpulkan bahwa selain dari yang tersebut dalam pasal itu tidak memiliki hak untuk mengajukan peninjauan kembali termasuk Jaksa Penuntut Umum. Berdasarkan ketentuan Pasal 263 ayat (1) berarti diterimanya Peninjauan Kembali yang diajukan Jaksa Penuntut Umum kepada Mahkamah Agung merupakan suatu peradilan sesat.

Peradilan sesat berasal dari frasa Rechterlijke Dwaling (belanda) yang kadang dibahasa-Indonesiakan dengan "kesesatan hakim". Penggunaan kata "hakim" sebagai pengganti kata rechterlijke dapat dimengerti sepenuhnuya karena peradilan identik dengan hakim. Hakim sebagai pengendali proses peradilan, sehingga jika proses peradilan yang dikendalikan oleh hakim yang memeriksa perkara dilakukan dengan salah jalan alias sesat dan menghasilkan putusan yang merugikan orang yang akan diadili atau ,menghasilkan putusan sesat maka dapat pula disebut "kesesatan hakim"13.

Menurut Adami Chazawi, kesesatan peradilan tidak semata-mata karena tersesat fakta (feitelijke dwaling), namun dapat juga kareana sesat dibidang hukum (dwaling omtrent het recht). Penulis menyetujui bahwa bukan termasuk peradilan sesat, apabila akibat putusan tidak merugikan terdakwa ${ }^{14}$. Pada diskusi publik di gedung Rektorat Universitas Jambi, Kemas Abdul Roni selaku pejabat Komisi Yudisial RI yang juga pernah menjadi Jaksa, mengemukakan bahwa menyetujui pendapat penulis bahwa diterimanya peninjauan kembali yang diajukan Mahkamah Agung merupakan suatu peradilan sesat seperti yang dikatakan Adami Chazawi dalam bukunya. Kemas Abdul Roni mengemukakan bahwa Jaksa Penuntut Umum tidak berhak mengajukan Peninjauan Kembali karena itu merupakan hak terpidana atau ahli warisnya, namun Jaksa selalu menang dalam mengajukan peninjauan kembali dan itu merupakan suatu kesesatan dalam peradilan Indonesia. ${ }^{15}$ Sesuai dengan landasan dibentuk dan jiwa lembaga PK, maka hanya terpidana saja yang berhak mengajukan permintaan peninjauan kembali. Ahli warisnya yang juga disebutkan berhak tidaklah berdiri sendiri, melainkan demi hukum mewakili terpidana. Artinya tidak terpisah dan berdiri sendiri, melainkan bagian dari terpidana. Oleh karena itu Negara tidak dapat mengajukan permintaan peninjauan kembali. Praktik kejaksaan yang menggunakan dasar Pasal 24 ayat (1) Undang-Undang No. 48 Tahun 2009 tetntang Kekuasaan Kehakiman tidak dapat dibenarkan.

Dengan demikian, Mahkamah Agung yang menerima permintaan peninjauan kembali penuntut umum dengan alasan mencari keadilan dengan cara menggali untuk

13 Adami Chazawi, "Lembaga Peninjauan Kembali (PK) Perkara Pidana", Cetakan Kedua, Sinar Grafika, Jakarta, 2011. Hal.131.

14 Ibid. hlm. 136.

15 Wawancara dengan Kemas Abdul Roni, Pejabat Komisi Yudisial RI, Tanggal 24 Oktober 2019. 
menemukan hukum tidak dapat dibenarkan. Mahkamah Agung sudah melampaui kewenangannya, karena Mahkamah Agung bukan lagi menggali hukum dengan jalan menafsirkan terhadap Pasal 263 ayat (1) KUHAP, melainkan di luar ketentuan semula, yang sesungguhnya menjadi kewenangan pembentuk undang-undang. Oleh karena itu, norma Pasal 263 ayat (1) KUHAP, khususnya subjek hukum yang berhak mengajukan peninjauan kembali tidak bisa dihubungkan dengan kata "pihak-pihak" dalam Pasal 24 ayat (1) Undang-Undang No. 48 Tahun 2009 secara sepotong dan tidak tuntas, dengan satu-satunya tujuan menghukum terdakwa yang sudah dibebaskan dengan putusan yang sudah bersifat tetap. Sebabnya Pasal 263 ayat (1) merupakan pihak dalam pengertian lex specialis, karena sudah mengacu pada pihak dalam hukum acara pidana. Sementara pihak-pihak yang dimaksud dalam Pasal 24 ayat (1) Undang-Undang No. 48 Tahun 2009 adalah pihak-pihak dalam lex generalis yang merupakan pengertian pihakpihak dalam semua jenis perkara. Sementara subjek hukum yang berhak mengajukan permintaan peninjauan kembali dalam Pasal 263 ayat (1) KUHAP yang merupakan lex specialis ${ }^{16}$.

Meskipun KUHAP telah berlaku lebih dari 30 tahun, namun berlakunya Pasal 263 KUHAP mengatur tentang upaya hukum luar biasa yang dinamakan peninjauan kembali, dalam pelaksanaannya masih menimbulkan pendapat kontroversisial ${ }^{17}$. pro dan kontra banyak terjadi dari berbagai sudut pandang ahli hukum. Dalam kenyataannya banyak pakar, praktisi, dan pengamat hukum yang berpendapat bahwa yang dapat mengajukan PK adalah terpidana dan ahli warisnya, sedangkan Jaksa Penuntut Umum yang mewakili masyarakat, korban kejahatan, dan mewakili negara tidak berhak mengajukan PK. Secara hukum formil jaksa penuntut umum tidak boleh mengajukan PK, akan tetapi atas dasar keadilan dan keseimbangan jaksa penuntut umum seharusnya memiliki hak yang sama seperti terpidana atau ahli warisnya. Dalam Pasal 263 ayat (3) KUHAP dapat diketahui bahwa selain terpidana atau ahli warisnya ternyata masih ada pihak yang dapat mengajukan PK, meskipun hak itu tidak disebutkan secara eksplisit. Oleh karena dalam peradilan perkara pidana hanya terdapat dua pihak yang saling berhadapan yaitu jaksa penuntut umum dan terdakwa atau terpidana, dapat dapat disimpulkan bahwa pihak lain itu adalah jaksa penuntut umum, maka dari itu jaksa penuntut umum memiliki hak yang sama dengan terpidana atau ahli warisnya dalam hal mengajukan peninjauan kembali, jaksa sebagai wakil negara, korban dan pihak ketiga.

Uji Materil terhadap Pasal 263 ayat (1) Undang-Undang Nomor 8 Tahun 1981 tentang Hukum Acara Pidana kepada Mahkamah Konstitusi dan diputuskan pada tahun 2016 dengan putusan Nomor 33/PUU-XIV/2016 menyatakan nahwa Pasal 263 ayat (1) KUHAP tidak bias ditafsirkan lain, karena pemaknaan yang berbeda terhadap norma akan menimbulkan ketidakpastian hukum dan ketidakadilan yang justru menjadikan inkonstitusional. Untuk itu Mahkamah Konstitusi perlu menegaskan bahwa demi kepastian hukum yang adil norma Pasal 263 ayat (1) U No. 8/1981 menjadi inkonstitusional jika dimakna lain.

16 R.M. Sudikno Mertokusumo, 2009, "Bolehkah Jaksa Mengajukan PK?” (artikel online), http://sudiknoartikel.blogspot.com. Diakses tanggal 11 Oktober 2019.

17 Yading Ariyanto, "Hak Penuntut Umum Mengajukan Peninjauan Kembali Dalam Perspektif Keadilan Hukum Di Indonesia", Artikel Program Magister Ilmu Hukum Universitas Brawijaya, Malang, 2013, hlm.8. 


\section{Aturan Khusus Mengenai Peninjauan Kembali Yang Diajukan Oleh Jaksa Penuntut Umum.}

Secara Filosofi dibentuknya Peninjauan Kembali semata-mata ditujukan bagi kepentingan terpidana, bukan kepentingan negara atau korban. Terkandung filosofis bahwa segara telah salah mempidana penduduk yang tidak berdosa berakibat telah dirampasnya keadilan dan hak-hak terpidana secara tidak sah. Berdasarkan Pasal 263 ayat (1) KUHAP tentunya Jaksa Penuntut Umum tidak berhak mengajukan peninjauan kembali, namun berdasarkan Pasal 24 ayat (1) Undang-Undang Republik Indonesia Nomor 48 Tahun 2009 tentang Kekuasaan Kehakiman yang berbunyi: "terhadap putusan pengadilan yang telah memperoleh kekuatan hukum tetap, pihak-pihak yang bersangkutan dapat mengajukan peninjauan kembali kepada Mahkamah Agung, apabila terdapat hal atau keadaan tertentu yang ditentukan dalam undang-undang".

Pasal 24 ayat (1) Undang-Undang Republik Indonesia Nomor 48 Tahun 2009 tentang Kekuasaan Kehakiman digunakan oleh Jaksa Penuntut Umum menjadi terobosan untuk melakukan peninjauan kembali seperti yang terjadi pada kasus Muchtar Pakpahakan, Ram Gulumal, Pollycarpus, Djoko Tjandra dan lain-lain. Namun Pasal 24 ayat (1) UU Kekuasaan Kehakiman tidak secara tegas dan jelas mengenai siapa saja pihak-pihak yang bersangkutan yang dapat mengajukan peninjauan kembali, dan lagi pula Undang-Undang Nomor 8 Tahun 1981 tentang Hukum Acara Pidana merupakan Lex Specialis yang mengatur tentang Hukum Acara Pidana yang tentunya juga mengatur upaya hukum luar biasa yaitu Peninjauan Kembali secara khusus. Berdasarkan Asas Lex Specialis Derogat Legi Generalis yang dapat diartikan "Hukum/ketentuan yang bersifat khusus menyampingkan hukum/ketentuan yang bersifat umum", maka jelas bahwa KUHAP lebih tepat menjadi acuan dibandingkan menggunakan undang-undang lainnya dalam hal melakukan permintaan peninjauan kembali kepada Mahkamah Agung.

Berdasakan KUHAP sudah cukup jelas unsur objektif maupun unsur subjektif dalam mengajukan peninjauan kembali. Unsur objektifnya adalah yang dapat diajukan peninjauan kembali adalah putusan pengadilan yang telah mempunyai kekuatan hukum tetap kecuali putusan bebas atau putusan lepas dari tuntutan hukum. Lalu berdasarkan unsur subjektifnya yang dapat mengajukan peninjauan kembali adalah terpidana dan ahli warisnya, maka selain daripada itu tidak berhak mengajukan permintaan peninjuan kembali. Oleh karena ketentuan-ketentuan dalam KUHAP yang tidak memberikan kedudukan terhadap Jaksa Penuntut Umum dalam mengajukan peninjauan kembali maka sangat diperlukan adanya aturan khusus yang mengatur tegas mengenai Jaksa Penuntut Umum agar dapat mengajukan peninjauan kembali, karena Jaksa Penuntut Umum merupakan pejabat fungsional Negara yang berwenang melakukan penuntutan dan Jaksa Penuntut Umum merupakan pengacara Negara yang melindungi kepentingan Negara dan Korban dalam hal penegakkan hukum.

Berdasarkan teori tujuan dari Gustav Radbruch yaitu Kepastian Hukum, Keadilan, dan Kemanfaatan. Penulis merangkul ketiga asas dari teori tujuan tersebut. Dalam hal mengajukan peninjauan kembali sangat diperlukan aturan khusus mengenai kedudukan Jaksa Penuntut Umum dalam mengajukan peninjauan kembali agar Jaksa Penuntut Umum tidak lagi melakukan terobosan terhadap Pasal 263 ayat (1) KUHAP yang tentunya dengan terobosan itu akan berdampak cacatnya kepastian hukum dari Pasal 263 ayat (1) itu sendiri, karena berdasarkan pasal 263 ayat (1) yang dapat mengajukan peninjauan kembali hanya terpidana dan ahli warisnya. Selain dari 
menjaga asas kepastian hukum dari Pasal 263 ayat (1) KUHAP dengan dibentuknya aturan baru maka dapat dirasakan keadilan dimata hukum apabila Jaksa Penuntut Umum diberi kesempatan untuk mengajukan peninjauan kembali. Berdasarkan Pasal 27 ayat (1) UUD Republik Indonesia Tahun 1945 "Segala warga negara bersamaan kedudukannya di dalam hukum dan pemerintahan dan wajib menjunjung hukum dan pemerintahan itu dengan tidak ada kecualinya". dari pasal ini dapat ditarik kesimpulan bahwa setiap warga negara kedudukannya sama di mata hukum.

Pasal ini juga menggambarkan asas keadilan bagi setiap warga negara. Lalu dalam Pasal 28D UUD 1945 yang berbunyi: "Setiap orang berhak atas pengakuan, jaminan, perlindungan, kepastian hukum yang adil serta perlakuan yang sama dihadapan hukum." dapat kita pahami bahwa kepastian hukum dan keadilan itu adalah dua tujuan dari hukum yang tidak bias dipisahkan. Setelah tercapainya kepastian hukum dan juga keadilan maka dapat kita rasakan kemanfaaatannya. Kemanfaatan hukum itu akan timbul setelah diwujudkannya kepastian hukum dan keadilan. Penulis menyimpulkan teori tujuan dari Gustav Radbruch yakni kepastian hukum, keadilan, dan kemanfaatan hukum adalah hal yang tidak bisa dipisahkan, ketiganya harus dicapai dalam sebuah penegakkan hukum agar tercapainya tujuan dari hukum.

Dalam teori Sistem Hukum Lawrence M. Friedman ia mengemukakan bahwa efektif dan berhasil atau tidaknya penegakkan hukum tergantung tiga unsur sistem hukum, yakni struktur hukum (structure of law), substansi hukum (substance of law), dan budaya hukum (legal culture). Struktur hukum menyangkut aparat penegakkan hukum, substansi hukum meliputi perangkat perundangan-undangan dan budaya hukum merupakan hukum yang hidup dalam suatu masyarakat. Struktur adalah pola yang menunjukkan tentang bagaimana hukum dijalankan menurut ketentuanketentuan formalnya. Struktur ini menunjukkan bagaimana pengadilan, pembuat hukum dan badan serta proses hukum itu berjalan dan dijalankan. Aspek lain dari sistem hukum adalah substansinya. Yang dimaksud dengan substansinya adalah aturan, norma, dan pola perilaku nyata manusia yang berada dalam sistem itu. Jadi substansi hukum menyangkut peraturan perundang-undangan yang berlaku yang memiliki kekuatan yang mengikat dan menjadi pedoman bagi aparat penegak hukum. Kultur hukum menyangkut budaya hukum yang merupakan sikap manusia terhadap hukum dan sistem hukum.

Relevansi teori sistem hukum dengan kajian posisi hukum korban kejahatan dalam sistem peradilan dikaji dalam dua aspek, yaitu asapek substansi hukum pidana yakni peraturan perundang-undangan hukum pidana (materiil dan formil) dan lembaga peradilan sebagai elemen struktur. Suatu sistem hukum pidana memiliki empat elemen substantif yaitu adanya nilai yang mendasari sistem hukum (philosophic), asas-asas hukum (legal principles), norma atau peraturan perundangundangan (legal rules), dan masyarakat hukum sebagai pendukung sistem hukum tersebut (legal society) ${ }^{18}$. Berkaitan dengan nilai dalam sistem substansi hukum, Soerjono Soekanto berpendapat bahwa hukum merupakan konkretisasi dari sistem nilai yang berlaku dalam masyarakat. Suatu keadaan yang dicita-citakan adalah adanya kesesuaian antara hukum dengan sistem nilai tersebut ${ }^{19}$.

18 Ajie Ramdan, "Kewenangan Penuntut Umum Mengajukan Peninjauan Kembali Pasca Putusan Mahkamah Konstitusi, "JIKH Volume. 11 No. 2 Juli 2017. hlm. 190.

19 Ibid. 
Peninjauan Kembali dalam kaitannya dengan teori sistem hukum dari Lawrence M. Friedman adalah bagaimana struktur hukum atau para penegak hukum menjalankan hukum berdasarkan ketentuan formalnya dalam hal peninjauan kembali sesuai Pasal 263 ayat (1) KUHAP aparat penegak hukum harus menjalankan ketentuan hukum dengan menjaga kepastian hukum dari pasal tersebut. Subtansi hukum yang berupa aturan, norma peraturan perundang-undangan yang berlaku yang memiliki kekuatan yang mengikat harus menjadi pedoman bagi aparat penegak hukum dan budaya hukum merupakan poin ketiga yang merupakan sikap manusia terhadap hukum dan sistem hukum, terutama sistem peradilan pidana. Lalu dalam hal hakim menemukan hukum atau penemuan hukum oleh hakim yang disebut (Rechtsviding) dapat dilihat dari beberapa kasus yang mana Jaksa Penuntut Umum mengajukan permintaan peninjauan kembali dan dikabulkan oleh Mahkamah Agung. Diterimanya PK Jaksa oleh Mahkamah Agung dapat dilihat bahwa Majelis Hakim peninjauan kembali telah menyampingkan Pasal 263 ayat (1) KUHAP dan menemukan hukum sendiri dengan mengabulkan PK Jaksa Penuntut Umum. Seharusnya, penegak hukum harus mencerminkan kepatuhan hukum dan tidak menyampingkan ketentuan undangundang. kepatuhan akan hukum dicerminkan oleh tingkah laku masyarakat, termasuk para penegak hukum (law enforcement official), yaitu polisi, jaksa, hakim, dan orangorang yang berpengaruh terhadap hukum ${ }^{20}$.

Penulis beranggapan penemuan hukum oleh hakim tidak cocok diterapkan di Indonesia karena Indonesia sendiri berkiblat hukum pada hukum eropa kontinental (civil law) sehingga diperlukan aturan tegas yang tertulis dalam peraturan perundangundangan mengenai kedudukan Jaksa dalam mengajukan peninjauan kembali. Seorang sarjana hukum pidana Jerman (1175-1833) Anselm von Feuerbach merumuskan asas legalitas secara mantap dalam Bahasa latin ${ }^{21}$ yaitu: Nulla poena sine lege "tidak ada pidana tanpa ketentuan undang-undang." Penulis menyamakannya dengan pendapat sendiri bahwa "tidak dapat dilakukan upaya hukum peninjauan kembali oleh jaksa tanpa adanya ketentuan undang-undang yang mengaturnya.

Penulis menyetujui Jaksa Penuntut Umum mengajukan permintaan peninjauan kembali apabila ada undang-undang yang mengaturnya karena Jaksa Penuntut Umum merupakan salah satu penegak hukum yang harus diberikan hak yang sama dalam mengajukan peninjauan kembali guna memberantas tidak pidana di Indonesia. Kebijakan penetapan pidana dalam perundang-undangan juga merupakan tahap yang strategis ${ }^{22}$ Prof Satjipto Rahardja mengatakan bahwa yang kalah di pengadilan belum tentu salah dan yang menang di pengadilan belum tentu benar ${ }^{23}$. Penulis beranggapan bahwa adil apa bila diberikan kewenangan kepada Jaksa Penuntut Umum dalam mengajukan Peninjauan Kembali demi kepentingan umum. Komariah mengemukan, keadilan harus didahulukan di atas kepastian hukum. Kepastian hukum yang tidak berkeadilan bukanlah kepastian hukum. ${ }^{24}$ Mochtar Kusumaatmaja dalam teori hukum

20 Kadri Husin dan Budi Rizki Husin, Sistem Peradilan Pidana Di Indonesia, Cetakan Pertama, Sinar Grafika, Jakarta, 2016, hlm.27.

21 Yahman, Karakteristik Wanprestasi Dan Tindak Pidana Penipuan, Edisi Pertama, Kencana, Jakart, 2014, hlm.42.

22 Hafrida, "Analisis Putusan Hakim Pengadilan Negeri Jambi Terhadap Pengguna/Pemakai Narkotika Dalam Perspektif Penanggulangan Tindak Pidana Narkotika," Vol 16, 2014. hlm.65.

23 www.indopos.co.id. Diakses Pada Tanggal 07-11-2019 Pada Pukul 08.55 WIB.

24 www.law.ui.ac.id 
pembangunnan mengatakan bahwa tujuan terakhir dari hukum adalah memberikan keadilan. ${ }^{25}$ Salah satu syarat dapat diajukannya Peninjauan Kembali adalah jika adanya Novum. Novum dapat artikan dengan adanya bukti baru berupa rekaman digital, dokumen elektronik (berdasarkan UU ITE), saksi mata, dan surat-surat bukti. Bukti baru tersebut telah ada sebelum perkara diputus, hanya saja belum dikuasai atau belum ditemukan. ${ }^{26}$ Ketentuan mengenai Peninjauan Kembali di dalam KUHAP tidak menjelaskan apa-apa saja yang dapat dikategorikan Novum begitu pula dengan Undang-Undang lainnya.

Dalam hal mengajukan Peninjauan Kembali sejauh ini belum ada undang-undang yang secara tegas memberikan hak kepada Jaksa Penuntut Umum dalam mengajukan Peninjauan Kembali, Adapun di dalam Pasal 24 Undang-Undang Nomor 48 Tahun 2009 Tentang Kekuasaan Kehakiman hanya menyebutkan pihak-pihak yang bersangkutan dapat mengajukan peninjauan kembali jika terdapat keadaan tertentu yang ditentukan dalam undang-undang. Pihak-pihak yang bersangkutan dalam perkara pidana yakni terpidana dan Jaksa Penuntut Umum yang saling berlawanan, sehingga dapat disimpulkan Jaksa dapat mengajukan permintaan peninjauan kembali. Namun dalam hal ini maka dapat dilihat juga ketidakpastian hukum mengenai kedudukan Jaksa Penuntut Umum karena tidak secara tegas disebutkan dalam undang-undang. Disisi lain Jaksa Penuntut Umum merupakan pejabat fungsional Negara yang membela kepentingan Negara seharusnya diberikan kedudukan yang sama yakni dapat mengajukan peninjauan kembali agar terciptanya suatu keadilan serta kemanfaatan yang juga seiring dengan kepastian hukum.

Gustav Radbruch mengemukakan ada tiga tujuan hukum yaitu kepastian, keadilan, dan kemanfaatan. Tidak jarang antara kepastian hukum berbenturan dengan keadilan, kepastian hukum dengan kemanfaatan. Dapat diambil contoh dalam sebuah perkara hukum, kalau hakim diharuskan mengambil keputusan yang adil maka rasa adil dari pihak lain tentu akan dikorbankan. Jika ingin menegakkan keadilan maka tentu kemanfaatan dan kepastian hukum harus dikorbankan. Keadilan bisa saja diutamakan dan mengorbankan kemanfaatan. Maka atas teorinya Gustav Radbruch mengajarkan adanya skala prioritas yang harus dijalankan, dimana prioritas pertama selalu keadilan, kemudian kemanfaatan, dan terakhir barulah kepastian. ${ }^{27}$ Penulis tidak sependapat dengan Gustav Radbruch bahwa yang diutamakan adalah keadilan karena menurut penulis di Indonesia sendiri yang menganut Civil Law seharusnya mengutamakan kepastian hukum, karena dari kepastian hukum itulah akan dirasakan keadilan, serta kemanfaatan hukum. Penulis ini merangkul ketiga tujuan hukum dari Gustav Radbruch tersebut menjadi selaras dan terwujud ketiga-tiganya dengan direvisinya ketentuan dalam KUHAP mengenai kedudukan Jaksa Penuntut Umum dalam mengajukan Peninjauan Kembali. Dengan diberikannya kedudukan kepada Jaksa Penuntut Umum untuk mengajukan Peninjauan Kembali maka terciptanya suatu keadilan, kemanfaatan, dan kepastian hukum.

\section{SIMPULAN}

25 Ibid.

26 hukum-hukum.com Diakses Pada Tanggal 10-01-2020 Pada Pukul 23.19 WIB.

27 Jaka Mulyata, "Keadilan, Kepastian, Dan Akibat Hukum Putusan Mahkamah Konstitusi Republik Indonesia", Tesis Fakultas Hukum Universitas Sebelas Maret, Surakarta, 2015, hlm.12. 
Berdasarkan pembahasanyang telah diuraikan, maka dapat disimpulkan sebagai berikut: Sesuai dengan Pasal 263 ayat (1) KUHAP Jaksa Penuntut Umum tidak berhak mengajukan peninjauan kembali, karena yang berhak mengajukan peninjauan kembali hanya terpidana dan ahli warisnya dan peninjauan kembali tidak bisa dilakukan terhadap putusan bebas atau putusan lepas dari segala tuntutan hukum. Beberapa permintaan peninjauan kembali yang diajukan oleh Jaksa Penuntut Umum yang pernah diterima oleh Mahkamah Agung merupakan suatu terobosan hukum yang berdampak cacatnya kepastian hukum dari Pasal 263 ayat (1) KUHAP. Serta diperlukan pula aturan khusus mengenai peninjauan kembali yang diajukan oleh Jaksa Penuntut Umum, sehingga terwujudnya keadilan, kepastian hukum, dan kemanfaatan hukum, Serta Jaksa Penuntut Umum dapat memberantas tindak pidana secara maksimal dalam tugasnya sebagai pejabat fungsional Negara yang memiliki wewenang melakukan penuntutan.

\section{DAFTAR PUSTAKA}

\section{Dokumen Hukum}

Republik Indonesia. Undang - Undang tentang Hukum Acara Pidana, Nomor 8 Tahun 1981.

Republik Indonesia Undang - Undang tentang Kejaksaan Republik Indonesia, Nomor 16 Tahun 2004.

\section{Buku}

Andi Sofyan dan Abd. Asis. Hukum Acara Suatu Pengantar. Kencana Pramedia Group. Jakarta. 2014.

Bahder Johan Nasution, Metode Penelitian Ilmu Hukum, Mandar Maju, Bandung, 2016.

Chazawi, Adami. Lembaga Peninjauan Kembali (PK) Perkara Pidana, Cetakan Kedua. Sinar Grafika, Jakarta, 2011.

Hamrat Hamid dan Harun M. Husein. Pembahasan Permasalahan KUHAP Bidang Penuntututan dan Eksekusi Dalam Bentuk Tanya Jawab. Cetakan Kesatu. Sinar Grafika, Jakarta,1992.

Hma Kuffal. Penerapan KUHAP dalam Praktek Hukum. Edisi Revisi. Cetakan Kesembilan. Universitas Muhammadiyah, Malang, 2007.

Kadri Husin dan Budi Rizki Husin. Sistem Peradilan Pidana Di Indonesia. Cetakan Pertama. Sinar Grafika, Jakarta Timur, 2016.

Yahman, Karakteristik Wanprestasi Dan Tindak Pidana Penipuan, Edisi Pertama, Kencana, Jakart, 2014. 


\section{Jurnal/ Majalah Ilmiah}

Ajie Ramdan, "Kewenangan Penuntut Umum Mengajukan Peninjauan Kembali Pasca Putusan Mahkamah Konstitusi, "JIKH Volume. 11 No. 2 Juli 2017.

Hafrida, "Analisis Putusan Hakim Pengadilan Negeri Jambi Terhadap Pengguna/Pemakai Narkotika Dalam Perspektif Penanggulangan Tindak Pidana Narkotika," Vol 16, 2014.

Sahuri Lasmadi. Tumpang Tindih Kewenangan Penyidikan Pada Tindak Pidana Korupsi Dalam Perspektif Sistem Peradilan Pidana. Artikel Dosen Fakultas Hukum Universitas Jambi.

Yayang Susila Sakti, "Peninjauan Kembali oleh Jaksa Penuntut Umum antara Kepastian dan Keadilan,"Arena Hukum Volume 7, No. 1. Edisi April 2014.

Yading Ariyanto, "Hak Penuntut Umum Mengajukan Peninjauan Kembali Dalam Perspektif Keadilan Hukum Di Indonesia", Artikel Program Magister Ilmu Hukum Universitas Brawijaya, Malang, 2013.

Yayang Susila Sakti, "Peninjauan Kembali oleh Jaksa Penuntut Umum antara Kepastian dan Keadilan,"Arena Hukum Volume 7, No. 1. Edisi April 2014.

\section{Skripsi/ Tesis}

Asriandi, "Kepastian Hukum Peninjauan Kembali Pasca Putusan Mahkamah Konstitusi Nomor 34/PUU-XI/2013 dan Surat Edaran Mahkamah Agung Nomor \& Tahun 2014 Di Pengadilan Negeri Makassar ",Skripsi Sarjana Hukum UIN Alauddin, Makassar, 2017, hlm. 12.

Jaka Mulyata, "Keadilan, Kepastian, Dan Akibat Hukum Putusan Mahkamah Konstitusi Republik Indonesia", Tesis Fakultas Hukum Universitas Sebelas Maret, Surakarta, 2015, hlm.12.

\section{Internet}

R.M. Sudikno Mertokusumo, 2009, "Bolehkah Jaksa Mengajukan PK?" (artikel online), http://sudiknoartikel.blogspot.com. Diakses tanggal 11 Oktober 2019. 